\title{
DESAIN KONSEPTUAL KAWASAN AGROWISATA CIGANJUR JAKARTA DENGAN KONSEP EKODESAIN
}

\author{
Rahmat Rejoni', Andrianto Kusumoarto ${ }^{2}$ \\ ${ }^{1}$ Universitas Indraprasta PGRI, Program Studi Arsitektur \\ rahmat.rejoni@unindra.ac.id \\ ${ }^{2}$ Universitas Indraprasta PGRI, Program Studi Arsitektur \\ andrianto.kusumoarto@unindra.ac.id
}

\begin{tabular}{ll}
\hline \multicolumn{2}{l}{ Informasi artikel } \\
\hline Sejarah & \\
artikel: & \\
Diterima & 23 September 2021 \\
Revisi & 29 September 2021 \\
Dipublikasikan & 30 September 2021
\end{tabular}

\section{Kata kunci:}

Penataan Kawasan

Perkotaan

Pertanian

Ruang Terbuka Hijau

Komunitas

\begin{abstract}
ABSTRAK
Kota Jakarta sebagai Ibu Kota Negara Republik Indonesia berusaha memberikan kenyamanan dan keamanan kepada penduduk dan pengunjungnya. Salah satu rasa nyaman dapat diberikan melalui penataan dan pengembangan serta pembangunan Ruang Terbuka Hijau Kawasan Perkotaan (RTHKP). Salah satu jenis RTHKP adalah kawasan pertanian (perkebunan). Kawasan pertanian yang hadir di tengah-tengah kota merupakan komponen perkotaan yang menarik dan dapat digunakan sebagai kawasan agrowisata. Salah satu kebun pembibitan yang dikelola oleh UPT Pusbangbenih dan Proteksi Tanaman berada di Ciganjur, Jakarta Selatan. Metode yang digunakan adalah pendekatan expert and public participatory dan desain berbasis komunitas (community based design). Dengan melakukan pengamatan lapangan berupa kondisi tapak, penutup dan penggunaan lahan, topografi, kemerangan lereng, visual, fasilitas serta drainase, maka dilakukan proses analisa tapak. Hasilnya merupakan suatu konseptual desain perencanaan kawasan agrowisata ciganjur yang dapat dimanfaatkan oleh dinas terkait dalam pengembangan suatu kawasan agrowisata kota, dengan kesimpulan direncanakan area untuk kegiatan pendidikan dan pelatihan budidaya tanaman alpukat campedak dan belimbing serta kegiatan lainnya seperti kegiatan pendidikan dan pelatihan pengelolaan kawasan agrowisata.
\end{abstract}

Key word:

Agriculture

Area Arrangemnet

Community

Green open space

Urban

\begin{abstract}
Jakarta City as the capital city of the Republic of Indonesia strives to provide comfort and security to its residents and visitors. One of the comforts can be provided through the arrangement and development and construction of Urban Green Open Spaces (RTHKP). One type of RTHKP is an agricultural area (plantation). The agricultural area that is present in the middle of the city is an attractive urban component and can be used as an agro-tourism area. One of the nurseries managed by the UPT Pusbangbenih and Plant Protection is located in Ciganjur, South Jakarta. The method used is an expert and public participatory approach and communitybased design. By conducting field observations in the form of site conditions, land use, topography, slope, visuals, facilities and drainage, a site analysis process is carried out. The result is a conceptual design for the Ciganjur agro-tourism area planning, with the conclusion that an area is planned for education and training activities for the cultivation of campedak and starfruit avocados as well as other activities such as education and training in the management of agro-tourism areas.
\end{abstract}

\section{PENDAHULUAN}

Kota Jakarta sebagai Ibu Kota Negara Republik Indonesia berusaha memberikan kenyamanan dan keamanan kepada penduduk dan pengunjungnya. Salah satu rasa nyaman dapat diberikan melalui penataan dan pengembangan serta pembangunan Ruang Terbuka Hijau Kawasan Perkotaan (RTHKP). Berdasarkan hasil penelitian bahwa Luas Ruang Terbuka Hijau (RTH) di Jakarta terutama di Jakarta Selatan dalam periode 5 tahun (tahun 2002-2007) berkurang sebesar 362,21 ha (Sitorus et al, 2011), hal ini juga diperkuat dengan penelitian Setiowati et al (2020), perencanaan RTH di Jakarta menurun sejak tahun 1965, dikarenakan alih fungsi lahan menjadi lahan terbangun. Kota Jakarta berupaya mencapai 
luas ruang terbuka hijau kawasan perkotaan sebesar $20 \%$. Berbagai jenis RTHKP di Kota Jakarta hadir untuk masyarakat. Salah satu jenis RTHKP adalah kawasan pertanian (perkebunan).

Kawasan pertanian yang hadir di tengah-tengah kota merupakan komponen perkotaan yang menarik dan dapat digunakan sebagai kawasan agrowisata. Salah satu kebun pembibitan yang dikelola oleh UPT Pusbangbenih dan Proteksi Tanaman berada di Ciganjur, Jakarta Selatan. Kebun bibit ini memiliki beberapa koleksi tanaman khas Jakarta yang telah dibibitkan dan dikembangkan sebagai tugas pokok dan fungsi dari UPT Pusbangbenih dan Proteksi Tanaman. Beberapa sarana dan prasarana telah dilengkapi di dalam Kawasan Kebun Bibit Ciganjur ini menuju kawasan agrowisata. Untuk mengembangkan konsep agrowisata pada suatu kawasan memperhatikan status kawasan (Nanda et al, 2017). Kawasan kebun bibit ini direncanakan sebagai kawasan wisata pertanian, pendidikan dan pelatihan pengembangan benih dan proteksi tanaman, percontohan pengembangan tanamantanaman khas Jakarta, sesuai dengan peraturan DKI Jakarta tentang Rencana Tata Ruang Wilayah dan Peraturan Zonasi Kota Jakarta.

Di Kawasan Kebun Bibit Ciganjur terdapat beberapa permasalahan dikaitkan dengan misi pengembangan Kawasan Kebun Bibit Ciganjur sebagai kawasan agrowisata. Beberapa diantaranya yakni fungsi ruang kegiatan yang belum tertata dengan baik, antara satu fungsi ruang dan fungsi ruang lainnya masih ada yang tumpang tindih, belum ada beberapa fasilitas yang menunjang aktivitas agrowisata, dan terdapat beberapa fasilitas dan utilitas yang telah mengalami kerusakan. Keberadaan ruang-ruang aktivitas perlu direncanakan secara baik dimana antara satu ruang aktivitas dengan ruang aktivitas lainnya memiliki keterhubungan atau tidak memiliki keterhubungan ruang sehingga aktivitas di dalam kawasan agrowisata dapat dilakukan aman, nyaman, sehat, dan harmoni. Fasilitas-fasilitas harus direncakan untuk menunjukan aktivitas-aktivitas yang dilakukan di dalam kawasan agrowisata tersebut.

Program kegiatan urban farming dan kegiatan pengembangan kegiatan usaha pertanian pada skala kampong kota di DKI Jakarta merupakan faktor-faktor pendorong untuk pengembangan kawasan agrowisata di beberapa kebun bibit yang dikelola oleh DKPKP Provinsi DKI Jakarta. Selain itu munculnya gerakan kembali kepada alam (back to nature) juga mendorong munculnya gerakan penghijauan pada beberapa ruang-ruang di kota, hal ini senada dengan jurnal yang ditulis oleh Fauzi et al (2016), yang mengatakan bahwa Praktik pertanian perkotaan diterapkan dengan konsep berkelanjutan dan berwawasan lingkungan. Sehingga dengan adanya konsep seperti itu diharapkan dapat menciptakan lingkungan yang sehat, aman, nyaman, dan bersih. Salah satu kegiatannya yang saat ini merupakan kegiatan prioritas dari DKPP adalah kebun bibit sebagai kawasan agrowisata. Berdasarkan hal tersebut di atas, maka diperlukan penataan kebun bibit yang aman, nyaman, sehat dan harmoni dengan alam.

\section{METODOLOGI}

Kegiatan pengabdian masyarakat ini menggunakan pendekatan expert and public participatory (Hester, 1990) dalam melakukan identifikasi persepsi dan keinginan terhadap pengembangan kebun bibit Ciganjur tersebut, metode ini juga pernah dilakukan oleh Rejoni dan kusumoarto et al (2019 dan 2020) serta oleh kusumoarto et al (2018), yang menggunakan pendekatan desain berbasis komunitas (community based design). Persepsi dan keinginan didapatkan khusus dari pengelola kawasan, pakar di bidang pengembangan agrowisata, dan pejabat yang berwenang dalam pengembangan kawasan tersebut.

Sedangkan metode dalam membuat desain konseptual digunakan metode pendekatan ecodesign (Motloch, 2001). Didalam tulisan Wijaya (2019) terdapat pernyataan tentang pengertian Eco- 
design menurut Ken Yeang, yang mengatakan bahwa eco-design adalah mendesain sedemikian rupa sehingga lingkungan buatan manusia terintegrasi baik dengan lingkungan alam. Metode pendekatan ini merupakan metode dalam melakukan perencanaan dan desain lanskap yang berprinsip terhadap perlindungan terhadap kelestarian lingkungan, keamanan, kenyamanan dan kesehatan pengguna tapak, perlindungan estetika tapak, dan kesesuaian tapak untuk tujuan agrowisata di perkotaan.

Kegiatan desain konseptual kawasan agrowisata Ciganjur mengacu kepada tahapan kegiatan yang dikemukakan oleh Gunn (1994) dan White (1983). Tahapan kegiatan adalah: 1. Identifikasi kebijakan Pemerintah Daerah, 2. Public Hearing, 3. Penetapan Tujuan, 4. Inventarisasi Sumberdaya Kawasan, 5. Analisis tapak, 6. Sintesis, dan 6. Desain Konseptual.

\section{HASIL DAN PEMBAHASAN}

\section{Identifikasi Kebijakan Pemerintah Daerah}

Identifikasi dilakukan untuk mengetahui kebijakan Pemerintah Daerah terhadap pengembangan kebun bibit Ciganjur. Kebijakan diperoleh dari keputusan-keputusan dan peraturan perundangan lainnya dari Pemerintah Provinsi DKI Jakarta. Selain itu juga diperoleh melalui telaah Rencana Tata Ruang Wilayah (RTRW), Rencana Detil Tata Ruang Kota (RDTRK), dan Rencana Tata Hijau Kawasan Perkotaan (RTHKP).

\section{Partisipasi Publik}

Tahap selanjutnya adalah melakukan public hearing. Tahap ini merupakan tahap mengetahui persepsi dan keinginan pengelola, masyarakat, dan pemangku kepentingan lainnya. Pengembangan ke arah masa yang akan datang harus dicapai dalam rangka memenuhi keinginan-keinginan tersebut, sehingga perlu dirumuskan secara jelas terhadap keinginan semua pemangku kepentingan. Public hearing dilakukan saat mengidentifikasi persepsi dan keinginan, merumuskan alternatif fungsi dan aktivitas ruang, dan merumuskan desain konseptual pengembangan.

\section{Kondisi Tapak}

Kawasan Agrowisata Ciganjur saat ini merupakan kebun bibit. Tanaman yang dominan dibudidayakan adalah tanaman alpukat mentega, dan belimbing. Kawasan agrowisata Ciganjur terletak di Jl. Swadaya No. 63, RT.08, RW.02, Cipedak, Kecamatan Jagakarsa, Kota Jakarta Selatan,

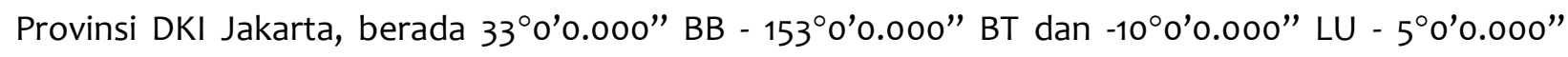
(Gambar 1). Luas Kawasan Agrowisata Ciganjur 13.2 Ha. Sebelah barat kawasan berbatasan dengan gedung sekolah SMK Negeri 63 Jakarta. Sebelah timur berbatasan dengan permukiman dan kebun penduduk. Sebelah utara berbatasan dengan permukiman penduduk. Sebelah selatan berbatasan dengan permukiman penduduk.

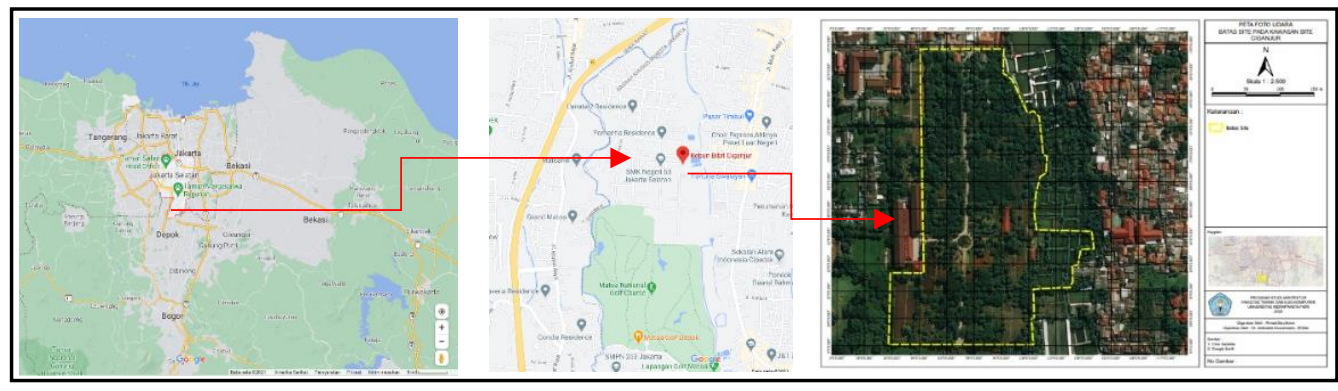

Gambar 1. Lokasi kawasan Agrowisata Ciganjur

Sumber : Dokumentasi Pribadi (2020) 


\section{Penutup dan Penggunaan Lahan}

Kawasan Agrowisata Ciganjur tersebar penutup dan penggunaan lahan sebagai berikut: bangunan, empang, jalan, jalur hijau, kebun indoor (nursery), ladang, pohon belimbing, dan pohon campuran. Sebaran penutup dan pengguna lahan dapat dilihat pada Gambar 2.

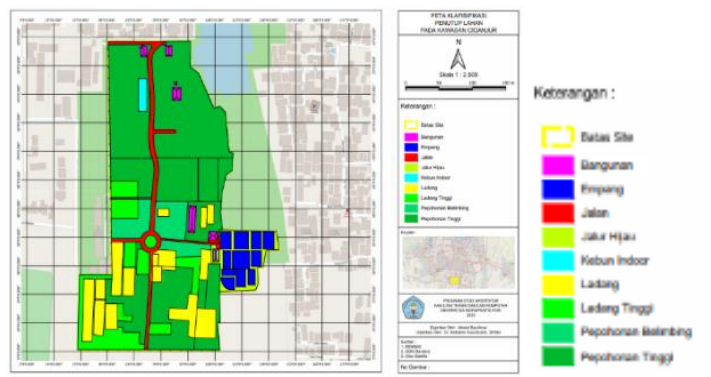

Gambar 2. Peta penutup dan penggunaan lahan Sumber : Survei lapangan (2020)

\section{Topografi dan Kemiringan Lereng}

Kawasan Agrowisata Ciganjur berada pada ketinggian antara 50 mdpl - 67 mdpl (Gambar 3a). Ketinggian terendah berada di sebelah timur yakni ke arah kolam ikan (empang) dengan kondisi terbengkalai. Area kebun bibit secara umum berada pada ketinggian 60-67 mdpl. Area untuk bangunan dan jalan tersebar pada ketinggian 63-65 mdpl. Kemiringan lereng di Kawasan Agrowisata Ciganjur terdistribusi $0-2 \%, 2-5 \%, 5-15 \%, 15-40 \%$, dan $>40 \%$ (Gambar 3b). Kemiringan lereng 0-2\% mendominasi kawasan tersebut. Kemiringan agak curam ke arah kolam ikan.

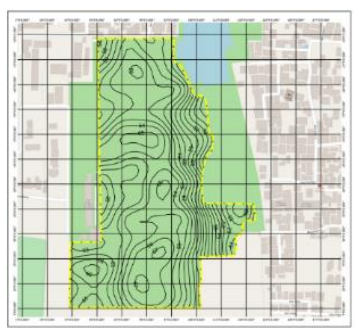

(a)

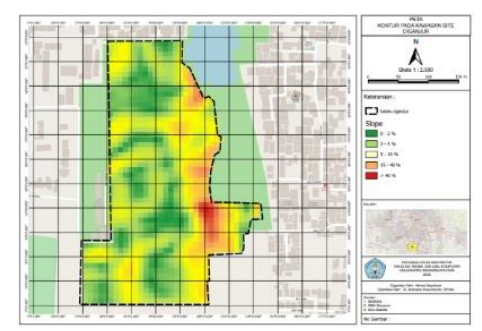

(b)

Gambar 3. Peta topografi (a), Peta kemiringn lereng (b) Sumber : Dokumentasi Pribadi (2020)

\section{Visual}

Pemandangan yang terlihat di kawasan ini didominasi oleh pemandangan kebun buah. Selain itu terdapat pemandangan kolam ikan, bangunan pembibitan, bangunan pengelola, bangunan pelatihan, bengkel, fasilitas penunjang dan lahan pembibitan. Foto-foto pemandangan dapat dilihat pada Gambar 4.

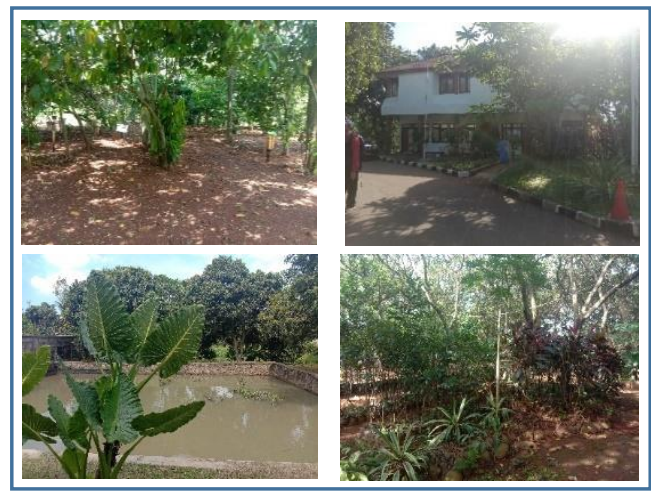

Gambar 4. Peta visual di kawasan Sumber : Dokumentasi Pribadi (2020) 


\section{Fasilitas di Kawasan Agrowisata Ciganjur}

Kawasan Agrowisata Ciganjur memiliki fasilitas-fasilitas untuk menunjang kegiatan rekreasi, kegiatan pembibitan, kegiatan pengelolaan, dan kegiatan konservasi. Fasilitas-fasilitas tersebut adalah kolam pancing, rumah pembibitan (nursery), lahan untuk pembibitas, jaringan irigasi penyiraman, gedung pengelola, parkir, pos jaga, bengkel, gedung pelatihan, mushola, kebun pembibitan, kebun buah endemik Jakarta, jalan setapak, jalan kendaraan bermotor, dan pagar keliling kawasan. Lokasi fasilitas-fasilitas ini tersebar di kawasan tersebut.

\section{Drainase}

Aliran air permukaan di kawasan ini mengarah ke lokasi yang lebih rendah ke arah timur dan barat. Ke arah timur aliran air permukiaan menuju sungai. Ke arah barat menuju drainase bawah tanah.

\section{Analisa Tapak}

Analisis kontur dan kemiringan lereng

Kemiringan lereng di kawasan ini berada pada kondisi yang datar (0-2\%), landai (2-5\%), bergelombang (5-15\%), agak terjal (15-40\%), dan sangat terjal (> 40\%). Kemiringan lereng yang datar umumnya digunakan untuk menempatkan bangunan. Kemiringan lereng yang datar hingga bergelombang digunakan sebagai area kebun buah dan pembibitan. Secara umum pohon buahbuahan yang ditanam sesuai dengan kondisi topografi kawaan tersebut. Berdasarkan kondisi topografi yang terdistribus di kawasan tersebut, beberapa dapat digunakan untuk area pembibitan, area rumah kaca, area rumah paranet, area rekreasi. Area dengan kemiringan yang terjal sebaiknya ditanami pohon untuk menjaga kestabilan lereng secara alami.

\section{Analisis visual}

Secara umum visual di dalam kawasan lebih banyak didominasi oleh kebun buah dan area pembibitan. Terdapat beberapa visual yang kurang baik seperti di area pemancingan, di area dengan lereng terjal. Secara umum area-area yang memiliki kondisi visual yang kurang baik ini merupakan area yang kurang intensif pemeliharaaan atau mengalami kerusakan. Terdapat jalur sirkulasi perputaran yang terpusat berbentuk lingkaran yang menjadi fokus (orientasi) visual pengguna ke segala arah (Gambar 5a). Ke luar kawasan terdapat beberapa kualitas visual. Ke arah utara terdapat visual yang kurang baik karena terbatasnya ruang pandang dan didominasi. Ke arah barat juga terdapat visual yang kurang baik karena terbatasnya ruang pandang dan didominasi oleh bangunan. Ke arah timur memiliki kondisi visual yang baik karena didominasi oleh kebun buah, begitu pula ke arah selatan (Gambar 5b).

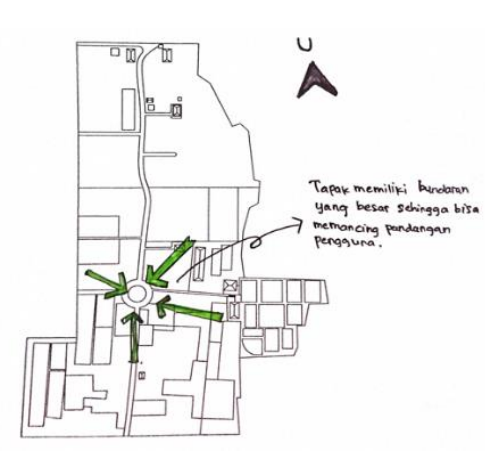

(a)

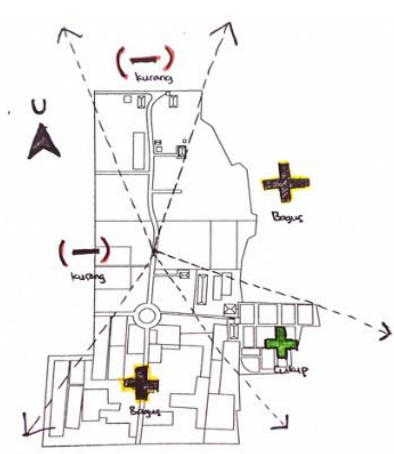

(b)

Gambar 5. Orientasi visual arah pengguna kawasan (a), arah luar kawasan (b) 


\section{Analisis Arah Aliran Air Permukaan}

Lokasi di bagian timur lebih rendah dibandingkan dengan lokasi lainnya (Gambar 6). Aliran air permukaan di lokasi ke arah timur dan sedikit ke arah barat. Air permukaan yang mengalir ke arah timur menuju sungai. Aliran air permukaan ke arah timur dapat dimanfaatkan untuk sarana rekreasi seperti kolam pemancingan ikan. Aliran air ke arah barat dapat digunakan untuk penyiraman tanaman di perkebunan dan di pembibitan tanaman.

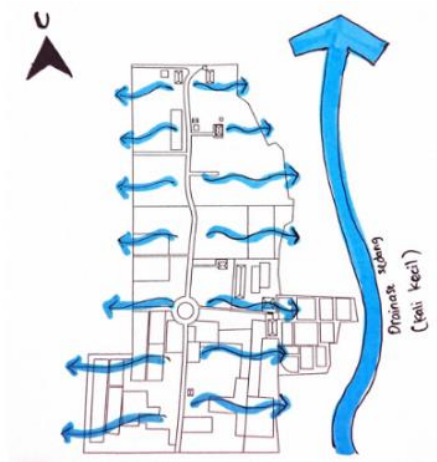

Gambar 6. Arah aliran air permukaan

\section{Analisis Arah Penyinaran Matahari}

Pada siang di musim kemarau, kawasan ini mendapatkan penyinaran matahari penuh. Adanya pohon-pohon buah yang tersebar hampir di seluruh kawasan dapat mengurangi panas dan terik sinar matahari ke arah kawasan tersebut. Arah lintasan penyinaran matahari dapat dilihat pada Gambar 7 .

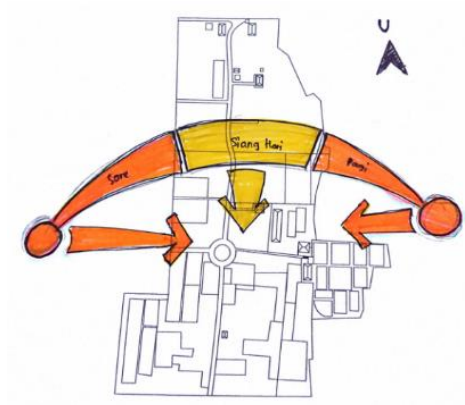

Gambar 7. Lintasan arah penyinaran matahari di kawasan

Analisis Arah Aliran Angin

Arah aliran angin dari barat dan timur (Gambar 8). Aliran angin ini dimanfaatkan untuk mengalirkan udara bersih dan menurunkan panas dari penyinaran matahari. Koridor-koridor jalan dibuat untuk mengalirkan angin, selain itu dapat dibuat koridor-koridor angin melalui penataan penanaman pohon-pohon.

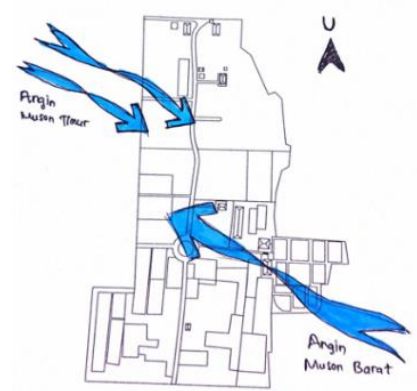

Gambar 8. Arah aliran di dalam kawasan 


\section{Analisis Sumber dan Arah Bunyi}

Sumber bunyi kebisingan berasal dari jalan raya di sebelah utara, aktivitas sekolah di sebelah barat, aktivitas pemancingan dan permukiman penduduk di sebelah timur. Sumber bunyi yang tidak dikehendaki dapat dihalangi dengan membuat dinding, menanam pohon-pohon yang memiliki tajuk dengan daun-daun yang lebar, mengatur jarak aktivitas dengan sumber bunyi.

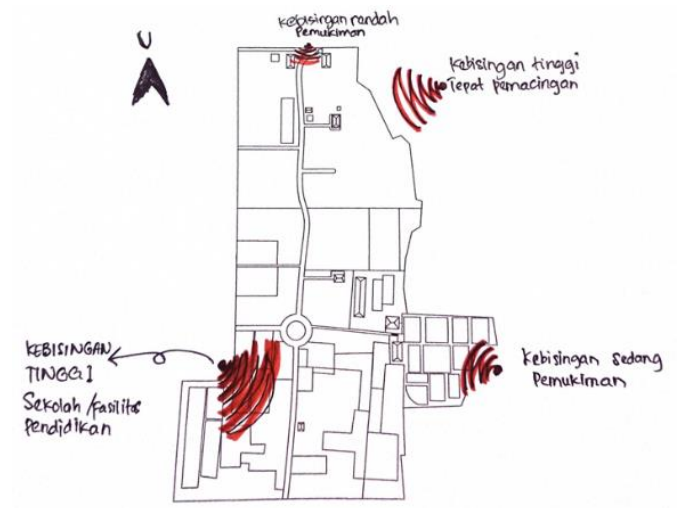

Gambar 9. Arah kebisingan dari sumber bunyi

\section{Analisis Tutupan Vegetasi}

Hampir seluruh kawasan ditutupi oleh pohon buah-buahan (Gambar 10). Tutupan vegetasi pohon dapat menurukan suhu udara dan memberikan kesegaran udara. Tutupan vegetasi pohon merupakan obyek utama untuk pengembangan Kawasan Agrowisata Ciganjur. Tutupan vegetasi pohon merupakan potensi yang sangat baik sebagai aktivitas utama agrowisata.

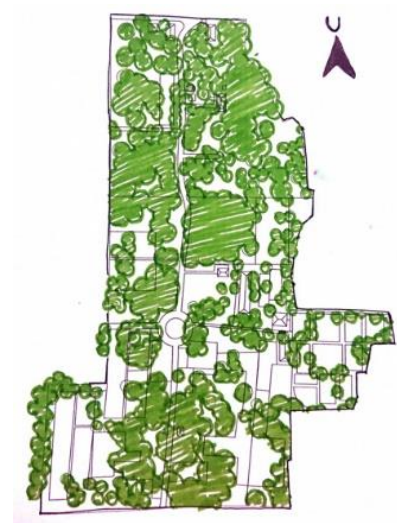

Gambar 10. Ditribusi tutupan vegetasi di dalam kawasan

\section{Konseptual Desain}

Fungsi-fungsi yang akan direncanakan dalam kawasan ini adalah konservasi, edukasi, rekreasi, dan pelayanan (Tabel 1). Aktivitas yang dilakukan di fungsi ruang konservasi adalah konservasi tanaman dan konservasi lahan. Aktivitas yang dilakukan di fungsi ruang edukasi adalah aktivitas budidaya tanaman alpukat campedak dan belimbing, aktivitas pendidikan dan pelatihan pertanian. Aktivitas yang dilakukan di fungsi ruang rekreasi adalah aktivitas pemancingan dan aktivitas outbond. Aktivitas yang dilakukan di fungsi ruang pelayanan adalah aktivitas pengelolaan jalur-jalur sirkulasi, aktivitas pengelolaan administrasi (kantor pengelola), aktivitas pengelolaan di tempat parkir, dan aktivitas pengelolaan di jalur inspeksi batas kawasan. Hubungan antar aktivitas dapat dilihat pada Gambar 11. Gambar rencana ruang dapat dilihat pada Gambar 12. 
Tabel 1. Fungsi, aktivitas, ruang, dan bentuk ruang

\begin{tabular}{|c|c|c|c|c|c|c|}
\hline \multirow[t]{2}{*}{ No } & \multirow[t]{2}{*}{ Fungsi } & \multirow[t]{2}{*}{ Aktivitas } & \multicolumn{3}{|c|}{ Ruang } & \multirow[t]{2}{*}{ Bentuk Ruang } \\
\hline & & & RTH & RTbn & RTbk & \\
\hline \multirow[t]{4}{*}{1.} & Konservasi & - Konservasi tanaman & $\sqrt{ }$ & & & $\begin{array}{l}\text { Kebun } \\
\text { pembibitan }\end{array}$ \\
\hline & & & $\sqrt{1}$ & & & Kebun buah \\
\hline & & - Konservasi lahan & $\sqrt{ }$ & & & $\begin{array}{l}\text { Kebun buah di } \\
\text { lereng terjal }\end{array}$ \\
\hline & & & & $\sqrt{ }$ & & $\begin{array}{l}\text { Dinding } \\
\text { penahan tanah }\end{array}$ \\
\hline \multirow[t]{4}{*}{2.} & Edukasi & $\begin{array}{l}\text { - Budidaya tanaman } \\
\text { alpukat campedak }\end{array}$ & $\sqrt{ }$ & & & $\begin{array}{l}\text { Kebun } \\
\text { pembibitan } \\
\text { buah alpukat } \\
\text { campedak }\end{array}$ \\
\hline & & $\begin{array}{l}\text { - Budidaya tanaman } \\
\text { belimbing }\end{array}$ & $\sqrt{ }$ & & & $\begin{array}{l}\text { Kebun } \\
\text { pembibitan } \\
\text { buah belimbing }\end{array}$ \\
\hline & & $\begin{array}{l}\text { - Pendidikan dan } \\
\text { pelatihan pertanian }\end{array}$ & $\sqrt{ }$ & & & $\begin{array}{l}\text { Kebun } \\
\text { pembibitan } \\
\text { (nursery) }\end{array}$ \\
\hline & & & & $\sqrt{ }$ & & $\begin{array}{l}\text { Gedung } \\
\text { pendidikan dan } \\
\text { pelatihan }\end{array}$ \\
\hline \multirow[t]{5}{*}{3.} & Rekreasi & $\begin{array}{l}\text { - Kegiatan } \\
\text { pemancingan }\end{array}$ & & & $\sqrt{ }$ & $\begin{array}{l}\text { Kolam } \\
\text { pemancingan } \\
\text { dan plaza }\end{array}$ \\
\hline & & & & $\sqrt{1}$ & & Gazebo \\
\hline & & - Kegiatan outbond & & & $\sqrt{ }$ & $\begin{array}{l}\text { Lapangan } \\
\text { berumput dan } \\
\text { plaza }\end{array}$ \\
\hline & & & $\sqrt{ }$ & & & Kebun buah \\
\hline & & $\begin{array}{l}\text { - Olah raga (lari dan } \\
\text { jalan kaki) }\end{array}$ & & & $\sqrt{1}$ & $\begin{array}{l}\text { Jalur sirkulasi } \\
\text { (pedestrian dan } \\
\text { jalur kendaraan) }\end{array}$ \\
\hline \multirow[t]{4}{*}{4.} & Pelayanan & $\begin{array}{l}\text { - Pengelolaan jalur } \\
\text { sirkulasi }\end{array}$ & & & $\sqrt{ }$ & $\begin{array}{l}\text { Jalur sirkulasi } \\
\text { (pedestrian dan } \\
\text { jalur kendaraan) }\end{array}$ \\
\hline & & $\begin{array}{r}\text { - Pengelolaan } \\
\text { administrasi }\end{array}$ & & $\sqrt{1}$ & & $\begin{array}{l}\text { Gedung } \\
\text { pengelolaan } \\
\text { administrasi }\end{array}$ \\
\hline & & - Pengelolaan parkir & & & $\sqrt{ }$ & $\begin{array}{l}\text { Tempat parkir } \\
\text { kendaraan } \\
\text { motor dan } \\
\text { mobil }\end{array}$ \\
\hline & & $\begin{array}{l}\text { - Pengelolaan jalur } \\
\text { inspeksi }\end{array}$ & & & $\sqrt{ }$ & $\begin{array}{l}\text { Jalur sirkulasi } \\
\text { untuk inspeksi } \\
\text { di batas } \\
\text { kawasan }\end{array}$ \\
\hline
\end{tabular}

Keterangan

RTH: Ruang Terbuka Hijau; RTbn: Ruang Terbangun; RTbk: Ruang Terbuka

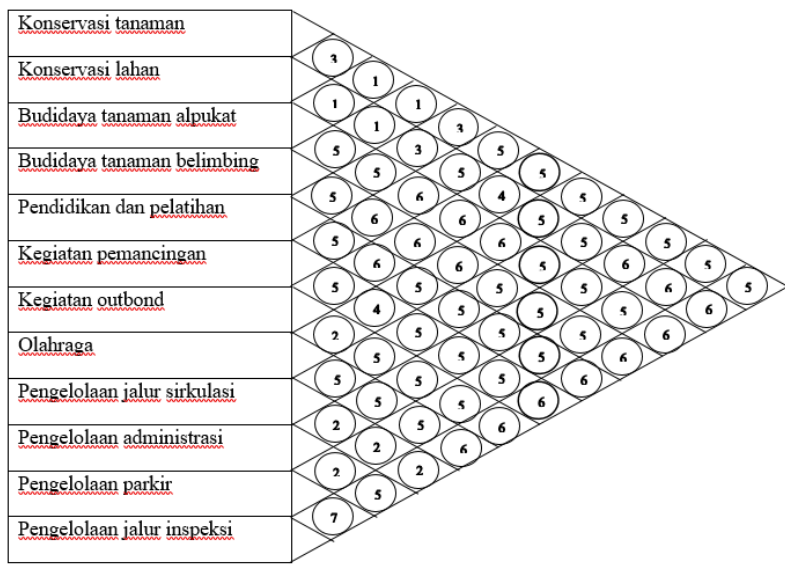

Keterangan :

Gambar 11. Hubungan aktivitas yang direncanakan di dalam kawasan 


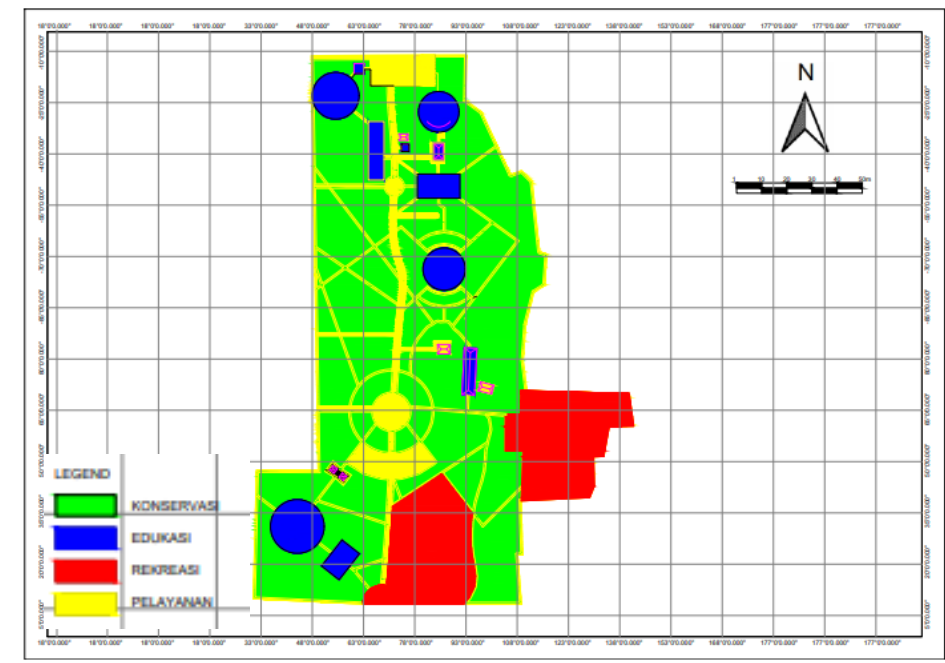

Gambar 12. Peta konsep ruang kawasan

\section{Perencanaan Kawasan Agrowisata Ciganjur}

Kawasan Agrowisata Ciganjur seluas $\pm 81.191 \mathrm{~m} 2$ direncanakan untuk aktivitas budidaya tanaman buah alpukat campedak dan belimbing. Aktivitas ini merupakan obyek wisata utama dimana direncanakan area mulai aktivitas pembibitan hingga pemanenan. Fasilitas yang direncanakan adalah kebun tanam terbuka, kebun pembibitan terbuka, nursery indoor (dome dan paranet), plaza untuk pemasaran hasil kebun, dan bangunan pembuatan kompos (Gambar 13). Area ini juga dilengkapi dengan pendopo untuk tempat pertemuan. Perspektif mata burung dapat dilihat pada Gambar 14 .

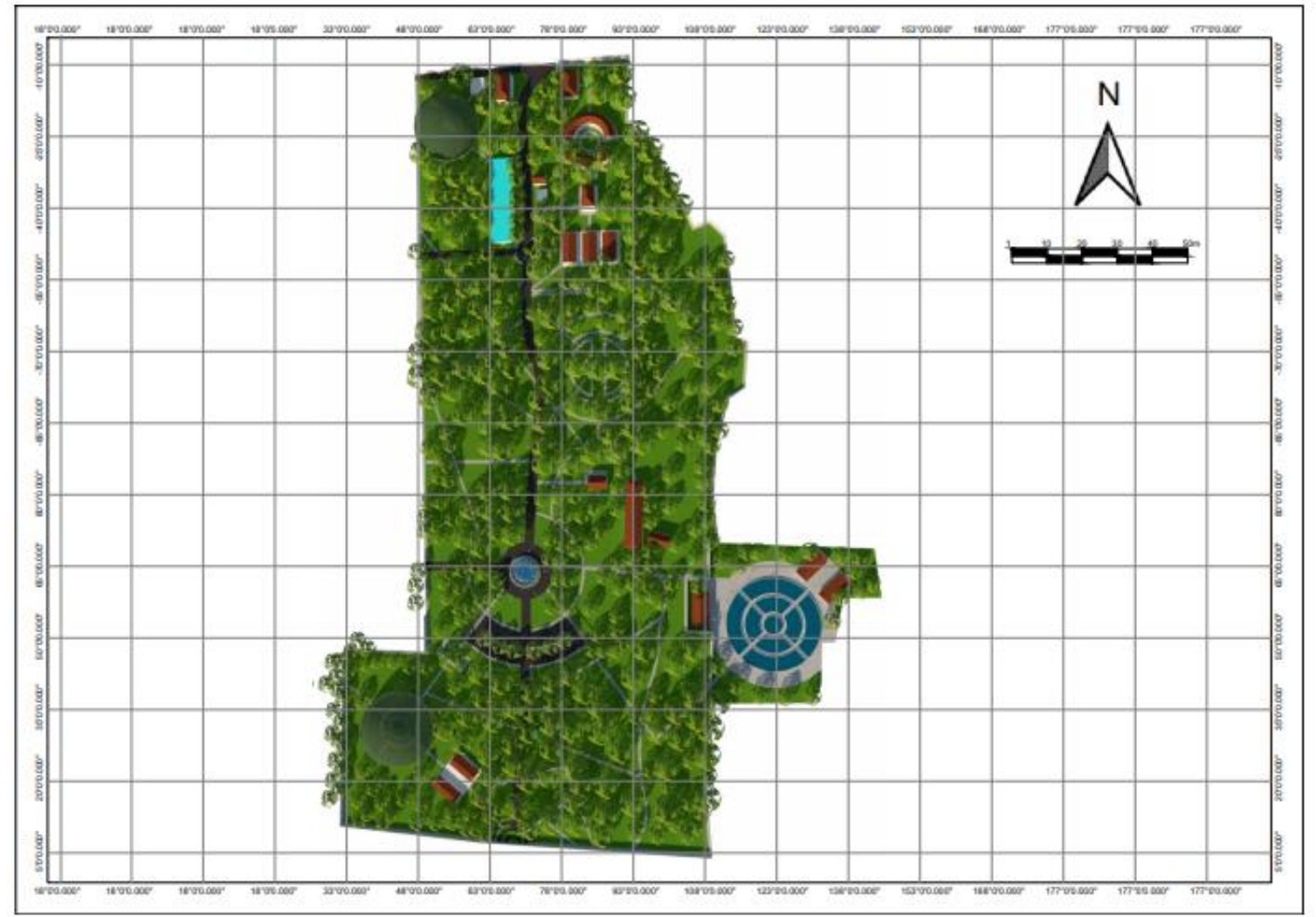

Gambar 13. Rencana kawasan agrowisata Ciganjur 


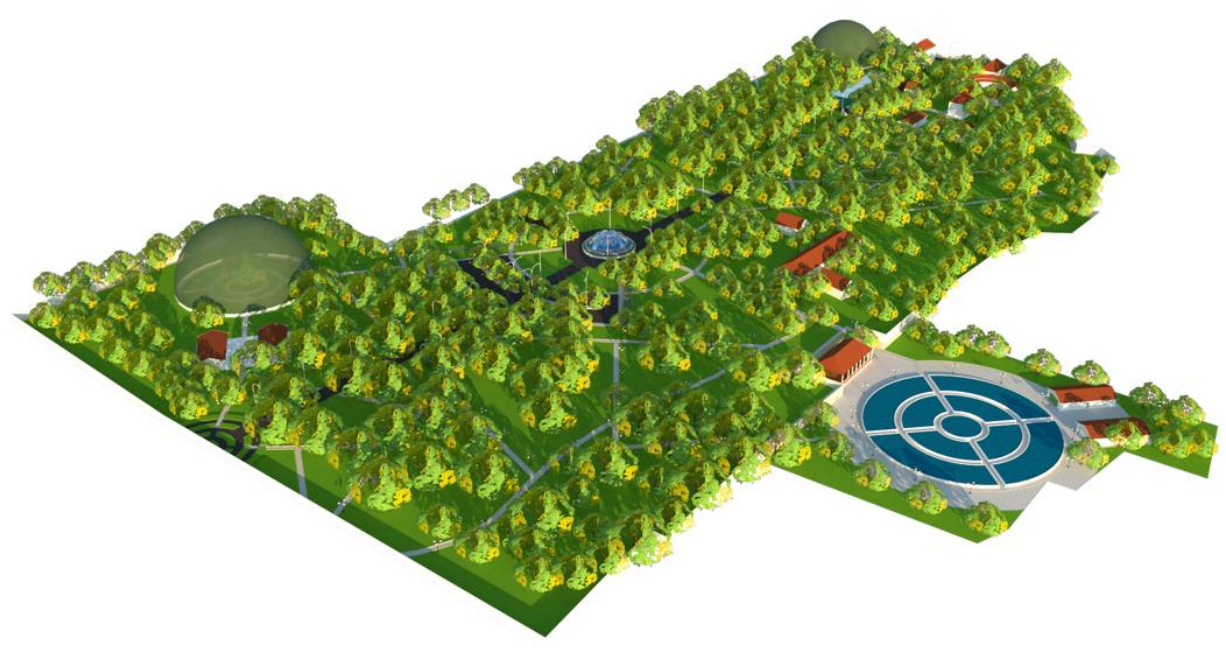

Gambar 14. Perspektif mata burung kawasan agrowisata Ciganjur

Di kawasan agrowisata Ciganjur juga direncanakan area untuk kegiatan pendidikan dan pelatihan budidaya tanaman alpukat campedak dan belimbing serta kegiatan lainnya seperti kegiatan pendidikan dan pelatihan pengelolaan kawasan agrowisata. Fasilitas ini dilengkapi dengan bangunan penginapan untuk peserta pendidikan dan pelatihan.

Di kawasan ini juga direncanakan area untuk kegiatan rekreasi dan olahraga yang terletak di sebelah timur (lokasi pemancingan). Lokasi ini juga dilengkapi dengan pendopo. Untuk kegiatan berolahraga selain disediakan area plaza juga direncanakan pedestrian untuk jalur pejalan kaki dan kegiatan lari. Selain itu direncanakan area outbond untuk kegiatan rekreasi untuk keluarga yang berkunjung. Area ini berada di dekat plaza dimana dapat digunakan untuk kegiatan bersama. Area outbond berada di bawah tegakan pohon di sebelah selatan.

Di kawasan ini direncanakan fasilitas-fasilitas untuk kegiatan pengelolaan, yaitu : bangunan pengelola, jalur sirkulasi kendaraan dan pejalan kaki, jalur inspeksi kawasan, dan area parkir kendaraan motor dan mobil. Bangunan pengelola direncanakan untuk aktivitas administrasi dan pengelolaan kawasan. Di jalur sirkulasi utama kendaraan juga direncanakan ada fasilitas tugu (landmark) dan air mancur. Jalur pedestrian direncanakan untuk digunakan sebagai pejalan kaki dan olahraga. Jalur inspeksi kawasan direncanakan untuk kegiatan memeriksa batas kawasan. Area parkir mobil dan motor cukup luas direncanakan berada di dekat tugu air mancur.

\section{PENUTUP}

\section{Simpulan}

Kebun bibit Ciganjur seluas $\pm 81.191 \mathrm{~m} 2$ direncanakan sebagai Kawasan Agrowisata Ciganjur. Ruang-ruang yang direncanakan pada kawasan ini adalah ruang konservasi, ruang edukasi, ruang rekreasi, dan ruang pengelolaan. Ruang-ruang yang direncanakan untuk mendukung aktivitasaktivitas sebagai obyek-obyek wisata.

Fasilitas-fasilitas direncanakan untuk mendukung berlangsungnya aktivitas-aktivitas di setiap ruang tersebut dengan baik. Fasilitas-fasilitas tersebut berupa : 1) ruang terbangun seperti gedung pengelolaan, gedung pendidikan dan pelatihan, pendopo, mushola, gedung peralatan (storage), rumah pembuatan kompos, dome nursery, dan paranet nursery; 2) ruang terbuka seperti kolam pemancingan, kolam air mancur, landmark (patung buah), jalur-jalur sirkulasi, parkir, fasilitas outbond; 3) ruang terbuka hijau seperti kebun pembibitan. 
Kawasan Agrowisata Ciganjur direncanakan tetap menggunakan aksesibilitas yang sudah ada saat ini (eksisting). Jalur sirkulasi direncanakan dapat menghubungkan seluruh fasilitas yang ada di kawasan ini. Kawasan ini direncanakan pula jalur inspeksi untuk memantau batas kawasan. Jalur sirkulasi utama direncanakan untuk jalur kendaraan mobil dan motor, sedangkan jalur pedestrian direncanakan untuk jalur pejalan kaki dan pengangkutan hasil kebun.

\section{Saran}

Kegiatan ini masih terbatas pada pembuatan konseptual desain. Kegiatan ini sebaiknya disarankan untuk dilanjutkan pada kegiatan perencanaan dan desain detil. Kegiatan perencanaan dan desain detil berguna sebagai acuan dalam proses pembangunan kawasan agrowisata Ciganjur.

\section{DAFTAR PUSTAKA}

Fauzi, A.R., Ichniarsyah, A.N., \& Agustin, H. (2016). Pertanian Perkotaan: Urgensi Peranan, dan Praktik Terbaik. Jurnal Agroteknologi, 10(1), 49-62. ISSN 2502-4906. Tersedia di: https://jurnal.unej.ac.id/index.php/JAGT/article/view/4339

Gunn CA. 1994. Tourism Planning : Basics, Concepts, Cases. Washington (US): Taylor \& Francis Publ.

Kusumoarto, A., \& Librianti, D. (2018). Desain Taman Lingkungan Permukiman Di Kota Bogor Berbasis Aktivitas Komunitas. 99- 108. Prosiding Seminar Nasional Universitas Indraprsta PGRI Jakarta, 1(1), 99-108. Tersedia di: http://proceeding.unindra.ac.id/index.php/dispanas2018/article/view/82/14

Motloch JI. 2001. Introduction to Landscape Design. Canada (US): John Wiley \& Sons Inc.

Nanda, F.F., Wulandari, L.D., \& Ramdlani, S. (2017). Konsep Agrowisata pada Lahan Konservasi Studi Kasus: Lahan Buah Condet, Jakarta Timur. Jurnal Mahasiswa Jurusan Arsitektur Universitas Brawijaya, 5 (1), tersedia di: http://arsitektur.studentjournal.ub.ac.id/index.php/jma/issue/view/15

[PEMPROVDKIJAKARTA] Pemerintah Provinsi DKI Jakarta. 2012. Peraturan Daerah Nomor 1 Tahun 2012 tentang Rencana Tata Ruang Wilayah Jakarta 2030.

[PEMPROVDKIJAKARTA] Pemerintah Provinsi DKI Jakarta. 2014. Peraturan Daerah Nomor 1 Tahun 2014 tentang Rencana Detail Tata Ruang dan Peraturan Zonasi.

Rejoni, R., Kusumoarto, A., Gunawan, A., \& Librianti, D. (2019). Pembangunan Taman Lingkungan Permukiman Villa Bogor Indah, Kota Bogor. Jurnal Lakar Arsitektur Universitas Indraprasta PGRI Jakarta, 2(1), 59-69. Doi: http://dx.doi.org/10.30998/lja.v2i01.3460

Rejoni, R., \& Kusumoarto, A. (2020). Rencana Kampung Tematik Kelurahan Cikaret Kota Bogor Berbasis Komunitas. Jurnal Lakar Arsitektur Universitas Indraprasta PGRI Jakarta, 3(1), 50-54. Doi: http://dx.doi.org/10.30998/lja.v3i01.5921

Setiowati, R., Hasibuan, H.S., \& Koestoer., R.H.T.S. (2020). Studi Komparasi Perencanaan Ruang Terbuka Hijau Perkotaan Antara Jakarta dan Singapura. Jurnal Lanskap Indonesia, 12(2), 5462. Doi: https://doi.org/10.29244/jli.v12i2.32409

Sitorus, R.P., Aurelia, W., Panuju, D.R. (2011). Analisis Perubahan Luas Ruang Terbuka Hijau dan FaktorFaktor yang mempengaruhinya di Jakarta Selatan. Jurnal Lanskap Indonesia, 3(1), 15-20. Doi: https://doi.org/10.29244/jli.2011.3.1.\%25p

Wijaya, I.K.M. (2019). Telaah Teori, Metode dan Desain Arsitektur Bioklimatik Karya Kean Yang. Jurnal Ilmiah Undagi Jurusan Arsitektur Universitas Warmadewa, 7(1), 36-41. Doi: https://doi.org/10.22225/undagi.7.1.1264.36-41 